\title{
TRADUCCIONS D'OBRES GREGUES A LA PENÍNSULA IBÈRICA*
}

\author{
GEMMA AVENOZA
}

\begin{abstract}
This essay examines the medieval Iberian translations of Greek works, a hundred titles which were rarely translated directly from their original language and, as usual in the medieval world, pieces that rarely transmit the name of the translator, although nearly 30 per cent name him. This corpus is examined dividing it into six subjects: spiritual life, philosophy, medicine and science, law, history and literature, seeking to understand the milieu in which they were produced, the reasons for the presence or absence of some titles in one or another of the Iberian territories, the public that demanded these translations and their textual transmission to the present day. This comparative study shows us that in the fourteenth century all translations share cultural milieu and readers, and that this situation changes in the second half of the fifteenth century, when in Castile versions are produced for the secular elite of the Court of John II (entertainment literature); neither in Portugal nor in Catalonia existed a similar milieu, settings where the works of a practical nature, philosophical, moral or spiritual reflection had an important presence (with a notable exception with regard to the Catalan version of Polybius, for example).
\end{abstract}

G

raeca sunt non leguntur fou una frase assumida i repetida en els ambients lletrats de l'edat mitjana arreu d'Europa, però tot i ser una afirmació taxativa no vol dir que no es tingués interès a conèixer les obres gregues, ans al contrari, en el món intelllectual i lletrat hom aprofità totes les oportunitats que tingué per fer-se amb textos que els permetessin accedir a les obres gregues, llegint-les en traduccions íntegres o més comunament en adaptacions i florilegis llatins. Aquestes versions passaren a les llengües vulgars i proporcionaren també als laics desconeixedors del llatí (o als clergues «poc llatins») un coneixement de la literatura grega. Ara bé, no cal esperar que el corpus d'obres traduïdes, copiades i admirades es correspongui amb el gust contemporani, car els segles XIII-XV tenen una altra percepció de les obres i, com veurem, un criteri utilitari, més enllà del de l'apreciació de la bellesa dels textos, és el que domina tot el panorama.

Per aproximar-nos a la difusió de les obres gregues a la península Ibèrica, ens hem servit fonamentalment de PHILOBIBLON (Faulhaber; Faulhaber, Gómez Moreno i Cortijo; Faulhaber i Gómez Moreno; Dias; Askins, Sharrer, Dias i Schaffer; Beltran i Avenoza; Beltran, Avenoza i Soriano), eina informàtica que ens permet accedir a tres grans bases de dades dedicades a l'estudi dels testimonis manuscrits $\mathrm{i}$ impresos que ens transmeten obra medieval hispànica.

"Aquesta investigació forma part del projecte d'investigació finançat per la CICYT FFI200803882 i cofinançat amb fons FEDER. 
A PHILOBIBLON trobem obres originals i obres traduides, obres que tenen un caire literari innegable i d'altres que són merament instrumentals. La major part de les traduccions parteixen d'originals llatins (directament o indirecta), però també hi ha traduccions de textos grecs, siríacs, hebreus, àrabs o de les diverses llengües europees. Una comparació superficial de les tres tradicions ens deixa veure que no sempre els corpus de traduccions coincideixen (amb algunes singularitats cridaneres), però en altres casos hi ha un interès comú a tota la península Ibèrica que féu sorgir arreu versions d'una obra determinada, la qual cosa va dibuixar una mena de cànon comú d'obres traduïdes.

Per tal de conèixer millor les característiques d'aquest corpus que respon a un interès compartit per tots els ambients lectors peninsulars, hem iniciat una anàlisi de les traduccions ibèriques, amb el benentès que rarament podrem parlar de traduccions directes, car la immensa majoria de les versions es feren a partir de textos llatins, àrabs (després traduïts al llatí), italians o francesos.

A més dels estudis sobre manuscrits i el corpus identificat a PHILOBIBLON, disposem d'estudis recents sobre les traduccions del grec que ens han fet un gran servei, com ara la visió general de les traduccions del grec a la Península (Bravo), el repertori d'obres catalanes traduïdes del grec i del llatí (Coroleu), els documents de treball dels projectes Translat $\mathrm{DB}$ sobre les traduccions medievals al català (Cabré i Pujol) i Sciència.cat DB sobre obres científiques en català (Cifuentes), els repertoris generals sobre traduccions i traductors (Alvar i Lucía; Alvar), la bibliografia crítica que es publica periòdicament (BBAHLM) $\mathrm{i}$ les nostres recerques personals sobre manuscrits i edicions antigues.

Per facilitar l'examen de les obres, hem dividit el corpus en sis matèries: vida espiritual, filosofia, medicina i ciència, dret, història i literatura. Així mateix, a l'hora d'esmentar les obres, emprem la forma llatina tradicional a l'edat mitjana per referir-s'hi, llevat d'uns pocs casos en què el seu caràcter de florilegis de difusió única en una de les llengües ibèriques ens inclina a preferir el nom de les seves versions vulgars.

Un altre punt a considerar prèviament és el del temps i l'espai (geogràfic i social) en què aquestes obres van ésser conegudes. Rarament una traducció ens informa del moment en què fou feta, per qui o per a qui. Així, doncs, la datació sol dependre d'elements externs que hem de valorar amb molta cura.

Del centenar de versions d'obres gregues aquí examinades, només coneixem el traductor d'unes trenta, cosa que suposa prop d'un trenta per cent del total. De molt pocs d'aquests traductors, posseïm dades biogràfiques. Destaquen extraordinàriament les minses informacions que ens han arribat sobre Bernat de Boïl (Libro de Ysaach) o Francisco de Melgaço (Speculum Monachorum), que permeten vincular-los a un determinat ambient cultural i social. Així, doncs, una de les fonts d'informació que ens ajuda a saber a quin públic van adreçar-se les versions és la transmissió manuscrita o impresa que ens les ha fet arribar, especialment aquells testimonis que cronològicament són més propers a la data que atribuïm a la traducció (tot i esperant les informacions que aporti l’inèdit treball de Borsari). 
Tampoc aquest és un plantejament absolutament sòlid i ple de certeses. Sovint la data a quo o ad quem d'una versió depèn de la datació que hem donat a un testimoni manuscrit, fonamentada en elements paleogràfics o formals, subjectes sempre a un marge de dubte, i són rars els testimonis amb un colofó datat. Tot $\mathrm{i}$ això, no tenim més remei que treballar amb aquests elements i fer extrapolació d'unes conjectures particulars a àmbits més generals, essent prudents, però, en la valoració dels resultats de les nostres observacions.

\section{OBRES TRADUÏDES DEL GREC}

\section{Vida espiritual}

Haurem de fer una petita distinció entre la vida espiritual i la història religiosa, nom sota el qual situaríem les narracions de caire hagiogràfic. Mentre que els textos propis de la vida espiritual correspondrien a una guia adreçada a aquells que han abandonat el món, els models transmesos per l'hagiografia implicarien un públic molt més ampli, entre el qual trobarien lloc tots els laics. Ambdues categories es poden influir mútuament, car hi ha obres que tot $\mathrm{i}$ tenir un paper notable dins l'edificació espiritual dels monjos, per algunes particularitats (caràcter emotiu o narratiu de la història, model assumible per un no-consagrat, etc.), passaren a formar part dels textos de meditació d'ús dels laics, els quals s'enriquiran amb obres escrites en llengua vulgar i amb d'altres traduïdes on triomfarà el vesant cristològic o el mariològic. El model de les vitae patrum es veurà substituït al llarg dels anys pel de la vitae Christi procedent de fonts llatines.

Ultra la presència a totes les tradicions peninsulars d'Isaac de Nínive (siríac $>$ grec $>$ llatí > català / castellà / portuguès) o de les Vitae patrum, Verba seniorum o Apophtehgmata patrum ${ }^{1}$ (grec $>$ llatí $>$ català / castellà ${ }^{2} /$ portuguès) que es troben en diverses versions, els textos espirituals són més nombrosos i molt més variats en portuguès que en les altres llengües. ${ }^{3}$ La presència de Johannes Climacus, l'Abat Isaac o les Vitae patrum està lligada inequívocament a l'ambient monàstic, car la major part dels testimonis (i/o traductors, copistes, etc.) tenen relació directa amb monestirs com el d'Alcobaça (en el cas dels portuguesos) o el de Montserrat (per a les versions catalana i castellana del Llibre d'Isaac o la difusió de la seva versió llatina —cf. Janeras-) o amb biblioteques

\footnotetext{
'Sota el títol de Vitae patrum, Verba seniorum o Apophtehgmata patrum circulaven una sèrie de textos d'origen $\mathrm{i}$ autoria diversos que recollien les històries dels pares del desert: vides, diàlegs i tota mena de passatges de caire semblant, que conformaren una tradició poc uniforme, car cada un dels reculls conservats pot introduir textos que els altres ignoren $\mathrm{i}$, al mateix temps, part de les Vitae patrum passen a integrar-se en reculls hagiogràfics posteriors que es transmeten al costat de les de la Legenda aurea (Cabré i Pujol 0.56).

${ }^{2}$ Si l'Aureola monachorum vel dicta patrum és un text assimilable a aquesta tradició.

3 Amb la reserva que les obres de Johannes Climacus en portuguès són molt breus i es conserven en testimoni únic aplegades en un còdex procedent del monestir d'Alcobaça (BN Alc 2 I3).
} 
que conserven fons procedents de la desamortització dels béns eclesiàstics. ${ }^{4}$ Altrament, bona part dels textos catalans foren traduïts al segle XIV.'

Només coneixem el nom d'un dels traductors d'obres espirituals: el monjo Bernat de Boïl, que dedicà la seva versió castellana d'Isaac, que veié la llum a través de la impremta, a un ardiaca de Daroca, Pedro Zapata. Aquesta versió es conserva també en un manuscrit de la Biblioteca de Palacio II/795 acabat de copiar al monestir de Sant Cugat del Vallès el febrer de I 484.

Els testimonis castellans d'Isaac de Síria trenquen la tendència que dibuixaven les versions peninsulars. Només una de les traduccions pot situar-se al segle xIV, ca. ad quem I 380 , i és una obra que interessaria inicialment més els ambients monàstics que no pas els laics, mentre que la resta se situen clarament en la segona meitat del segle xv.

Ultra aquesta traducció del Libro del abat Isaac, comptem amb la Regla sacada del libro del abat Isaac, manuscrit del segle xv conservat en testimoni únic procedent d'una important biblioteca nobiliària, la d'Isabel la Catòlica (Ruiz 450). Finalment, les Apophthegmata patrum trad. ca. I 380 ens han arribat en un únic manuscrit que fou del comte d'Haro.

Aquesta cronologia relativa permet dibuixar un canvi en el públic al qual van dirigides les versions vulgars d'aquest tipus d'obra amb un referent antic grec:

segle xiv: ambients monàstics (Alcobaça, Montserrat, etc.), llevat de la versió castellana dels Apophthegmata patrum (1380 ad quem).

segle xv: ambients laics lligats a la cort, llevat de la versió de Bernat de Boïl, monjo de Montserrat, dedicada a Pedro Zapata, ardiaca de Daroca.

La primera excepció a aquesta categorització és el manuscrit del comte d'Haro, Pedro Fernández de Velasco († I 470), en les mans del qual situem una traducció de finals del segle xIv. Hem de tenir present que en I 455 fundà a Medina de Pomar l'Hospital de la Vera Cruz per a acollir cavallers pobres, i entre els béns amb què el dotà s'inclö̈a una biblioteca que havia de satisfer les seves necessitats espirituals (Lawrance). ${ }^{6}$ No tenim cap document que vinculi la traducció dels Apophthegmata al comte d'Haro, però és un tipus d'obra que li podia interessar molt especialment en el moment de la fundació de l'hospital o en els seus darrers anys, quan hi visqué retirat. Així, doncs, una obra que hauria estat d'interès per als ambients monàstics durant el segle XIV es convertí el segle XV en material valuós per a acompanyar la meditació i la vida espirituals dels laics.

${ }^{4}$ Els fons dels convents foren dipositats en diversos centres que s'havien de fer càrrec de llur custòdia i conservació, cas de la Biblioteca Pública i Universitària, l’Arxiu de la Corona d'Aragó o l'Acadèmia de Bones Lletres, entre altres centres de Barcelona; la Biblioteca Pública i Universitària de València $i$, en general, les biblioteques públiques de cadascuna de les grans ciutats (com ara Palma). És evident que hi ha excepcions, car els Fons de la Real Biblioteca de El Escorial dipositats al monestir d'El Escorial no van patir cap trasbals per causa de la desamortització i que una gran quantitat de fons d'arreu d'Espanya van incorporar-se a la Real Academia de la Historia o a l'Archivo Histórico Nacional (Madrid), en lloc de les corresponents biblioteques provincials.

s Les traduccions conservades del Llibre d'Isaac (amb reserves) i una de les versions de les Verba seniorum serien del segle xv, mentre que la resta s'ubicarien al segle XIv.

${ }^{6}$ Bona part d'aquesta biblioteca es conserva avui dia a la Biblioteca Nacional de Madrid. 
Aquesta circumstància ens fa reflexionar sobre els ambients on sorgiren les versions de Johannes Climacus, l'Abat Isaac o de les Vitae patrum en cadascuna de les llengües. Les més primerenques estan lligades a centres monàstics (recordem que treballem amb els canals de difusió com un element més per situar llur origen i el públic), 7 mentre que al segle xv es troben també entre els llibres de nobles i grans senyors (reines com Maria de Castella, reina d'Aragó, o com Isabel I de Castella, o nobles com el comte d'Haro), que s'interessen per unes obres que els serveixen de suport en la seva formació espiritual. ${ }^{8}$ Les poques obres d'aquesta categoria que passaren a la impremta s'han integrat en aquest esperit i superaren els límits del textos entesos per a la formació dels monjos (Libro de Isaac a Saragossa per Hurus, 1489 i a Sevilla per Ungut i Polono en I 497, publicant-se en cadascun dels casos una traducció diferent, la primera del monjo montserratí Bernat de Boill i la segona d'autor desconegut). Els textos derivats de les Verba patrum es transformen en narracions exemplars que nodreixen les colleccions d'exempla. Es copien al segle xv al costat de miracles marians o s'integren des de molt abans a reculls hagiogràfics com la Legenda aurea.

El grup d'obres hagiogràfiques (en versions llatines anònimes $\mathrm{o}$ en les reelaboracions de Iacopo da Varazze) ens ha arribat en traduccions del segle xv; en són excepcions el Barlaam et Josaphat portuguès (I370-I400), la Vida de santa M. Egipcíaca portuguesa (I 275-I 325 ) i la Vitae Pelagiae castellana derivada de les Vitae patrum en la compilació de Pelagi ( 1380 ad quem) del manuscrit del comte d'Haro abans esmentat. Aquestes vitae, en català, tenen una tradició textual exclusivament impresa, mentre que en castellà i portuguès són més abundants els testimonis manuscrits, llevat de la Vitae Pelagiae present al Flos sanctorum portuguès (trad. de mitjan segle xv) transmesa per l'edició de Lisboa de $1513 .{ }^{9}$ La impremta assegura un públic més ampli i les nombroses edicions parlen d'un producte que es venia prou bé i del qual no s'identificava un origen grec, car eren assumides com a pròpies de la tradició llatina occidental.

Finalment, cal tractar de les obres de Basili de Cesarea i Joan Crisòstom, anomenat «Boca d'or», traduïdes només al castellà. Són deu peces de contingut homilètic o reflexions sobre els sagraments (la penitència, especialment) traduïdes al segle xv en l'entorn de la cort de Castella. Coneixem el nom de dos dels traductors (Pedro Díaz de Toledo per a Santillana i Alonso de Palenzuela per a la reina Isabel) $\mathrm{i}$ les característiques de les versions intermèdies. Díaz de Toledo emprà la llatina de Bruni del De libris gentilium de Basili i l'anònim que traduí

\footnotetext{
7 Són considerades obres prou importants com per a posar-les a la disposició d'aquells monjos que no tinguin una familiaritat suficient amb el llatí que els permeti seguir l'argumentació dels originals.

${ }^{8}$ La pietat de la reina Maria és ben coneguda i també ho és l'interès que la reina Isabel tenia pels textos religiosos i de pietat (Sabaté i Soriano). L'actitud de Pedro Fernández de Velasco no és pas massa llunyana de les d'aquelles grans senyores, car un cop vidu es retirà al monestir franciscà que ell mateix havia fundat a Medina de Pomar.

9 Els Flos sanctorum portuguesos es van imprimir a partir de I $5 \mathrm{I} 3$, però transmeten traduccions de mitjan segle $\mathrm{xv}$.
} 
també per al marquès de Santillana les seves Homilies, la llatina de Bessarion. Són obres que destaquen per ésser models d'oratòria religiosa d'estil elevat, que trobaria el seu públic entre el clergat al servei dels poderosos o que es movia (i es formava) en centres com Salamanca. En aquest públic devien pensar els impressors que a Múrcia (Ariño Roca I487) i a Sevilla (Tres compañeros alemanes I 499) posaren a la venda les edicions del Quod name de Joan Crisòstom i dels Sermons de Basili de Cesarea.

Així, doncs, les obres gregues més pròpiament acostades a la vida espiritual que es difonen al segle xv són aquelles que tenen un lligam clar amb l'oratòria, no les que serveixen de model de vida retirada al monjo. Fou el clergat secular de Castella qui en primer lloc hi estigué interessat i, tot seguit, s'hi sentiren atrets els nobles inclinats a una vida retirada sota la guia dels seus consellers espirituals. ${ }^{10}$ Aquest pas del textos espirituals més purs dels ambients monàstics a les elits religioses o nobles al segle Xv no es donà en català, on la pietat de la societat laica s'amarà dels textos dels Flos sanctorum i de les diverses Vitae Christi, mentre que el clergat no manifestà un interès especial que s'hagi concretat en la còpia o en la conservació dels textos.

\section{Història}

La nòmina de textos històrics no és gaire llarga, però sí força interessant: Xenofont (segles IV-III aC), Polibi (II aC), Plutarc i Josep Flavi (segles I-II), Herodià de Síria (segles II-III) i Eusebi de Cesarea (segle Iv) entre els més antics, i Joan Zonaras (segle XII) o la quasi contemporània Crònica de Morea (segle XIV), entre els més moderns. Cap d'aquestes obres no té traducció portuguesa i només dues, el De primo bello punico i les Vitae parallelae, conserven versions en més d'una llengua (català i castellà la primera i aragonès i castellà la segona). ${ }^{\text {II }}$ Si fem abstracció de les obres lligades a Juan Fernández de Heredia, totes les altres es troben estretament vinculades als ambients laics, ciutadans (en el cas del Polibi, traduït per Francesc Alegre per al conseller de Barcelona Antoni de Vilatorta) o als membres de la cort castellana. A més, coneixem el nom del traductor de gairebé totes (cinc sobre set), cosa que ens situa lluny de la humilitat sota la qual es protegien els religiosos del segle XIV, car tenim ara uns traductors que en general tenen un renom reconegut com a intelllectuals apreciats en el seu temps

\footnotetext{
${ }^{10}$ Com ara la duquessa de Palència, per a qui el seu confessor prepara un homiliari comentat on s'inclouen traduccions dels Evangelis. Alvar, en valorar la tipologia de les obres encarregades o dedicades als gran senyors de Castella, observa que aquests no encarreguen textos de contingut religiós, cosa que contrasta amb el fet que el quaranta per cent de les traduccions eren textos edificants «¿Para quién? Parece claro que para la baja nobleza y para las mujeres. Se puede afirmar que la renovación intelectual llegó de manos de los reyes y de la aristocracia. Signo de distinción» (Alvar 289).

${ }^{11}$ El Libro de los emperadores de Joan Zonaras en versió aragonesa procedeix d'una de catalana que s'ha perdut (Cacho Blecua).
} 
i que signen les seves obres, sense que s'hagi de menysprear el paper dels impressors, desitjosos de posar a la venda obres avalades per noms ben consolidats de l'elit intellectual.

El grup d'obres lligades a Fernández d'Heredia al segle xIV (un Plutarc, el Zonaras i la Crònica de Morea) poden considerar-se literatura de cort, que té com a destinatari el seu promotor, el gran mestre de l'orde de Sant Joan de Jerusalem, que les patrocinà, la qual cosa va generar una activitat intellectual semblant a la de l'ambient alfonsí del segle XIII (Cacho Blecua). Fernández de Heredia i els seus colllaboradors van treballar amb versions prèvies fetes en altres llengües (llatí, català, francès), però és ben possible que en alguns casos (com ara el Plutarc o el Zonaras), tinguessin present el text grec (clàssic o vulgar). Si això fos així, seria l'única peça traduïda directament del grec a una llengua vulgar peninsular en tota l'edat mitjana.

Les obres de caire històric esmentades responen als interessos dels ambients laics de la societat hispànica medieval quatrecentista:12 en el cas castellà clarament vinculades als ambients de la cort i la noblesa culta on creixien les llavors de l'Humanisme. Dues de les traduccions d'Alfonso de Palencia arribaren a la impremta: el De bello judaico de Josep Flavi (Sevilla, Ungut i Polak I 492) i el Plutarc (Sevilla, Ungut i Polak I49I), mentre que la resta de les obres tingué una tradició textual exclusivament manuscrita amb testimonis conservats que s'han transmès en l'entorn de la cort: a la papal de Roma la de Diego Guillén de Ávila d'Herodià de Síria, a la real de Castella la de Xenofont, i a la casa de Santillana la dels Canones d'Eusebi de Cesarea. Aquesta darrera va ser l'obra de caràcter més medieval de totes les històriques traduïdes durant el segle xv a la Península.

Les Antiquitates judaicae foren traduïdes per al rei Joan I ca. I $408^{13}$ i només coneixem aquesta traducció de l'obra de Josep Flavi a través de l'edició feta a Barcelona per Spindeler a despeses dels llibreters Sa Coma i Mir en I $482 .{ }^{14} \mathrm{El}$ Polibi català fou dedicat en 1472 a un conseller de Barcelona, coincidint amb el final de la guerra contra Joan II; en un moment d'agitació política com aquest, el concepte «literatura de cort» és qüestionable i, en tot cas, s'hauria de considerar també com a «cort» l'ambient que s'atribuïa el poder legítim, en aquest cas la Generalitat de Catalunya i la ciutat de Barcelona representada pel seu Consell de Cent, que podríem equiparar amb els ambients prehumanístics peninsulars del segle Xv.

\footnotetext{
${ }^{12}$ Llevat, és clar, de les versions de Josep Flavi que inclogueren els collaboradors d'Alfons el Savi en les seves obres històriques (Sánchez-Prieto Borja I xciii-xciv).

${ }^{13}$ Segons Riera (Presencia), la traducció és anònima i Pere Llopis no n’hauria estat el traductor, sinó el corrector de l'edició.

${ }^{14}$ Alvar i Lucía (187 n. 62) i Coroleu (899) esmenten una traducció castellana anònima de les Antigüedades judaicas de Josep Flavi, conservada a Santander, Menéndez y Pelayo M-54. Aquest manuscrit conté en realitat una traducció del Josifon hebreu (Avenoza, Versiones; Datos). Només disposem d'una versió castellana medieval de les Antiquitates, la d'Alonso de Palencia reeditada al segle XVi ( I 536, I 55 I) i no en sorgí una de nova fins a i 557, obra de Juan Martín Cordero, en dates molt allunyades de les que aquí considerem.
} 


\section{Dret}

Ens ha arribat una sola obra d'aquestes característiques, tot i que de manera indirecta, car només roman la notícia que abans de I426 a la cort de D. Joan I de Portugal es va fer una versió del Codicus de Justinià per a ús de la cambra règia i dels seus curials. El manuscrit no es conserva i no sabem en quina llengua estava la versió que es traduí ni quines n’eren les característiques. En tot cas, es tracta d'un text acollit en la cultura romanç per la seva importància com a font del dret.

\section{Medicina i ciència}

Bona part de la ciència grega que arribà a la Península i tingué versions en vulgar està vinculada a Claudi Galè de forma directa o indirecta (obres creades per ell, atribuïdes, o parts de les seves obres integrades en les d'autors més tardans). La major part es conserva en versió catalana (cinc de vuit); en castellà, només ens han arribat les del Libro que babla altamente de física i del Tesoro de los remedios, traduccions del segle $\mathrm{xv}$ de les quals sabem molt poc, llevat que el copista de la primera es deia Juan de Mayorica. Al portuguès es versionà el $D e$ anatomia a la segona meitat del segle xv, probablement vinculada al món universitari, car formà part del fons antic d'Évora. is Totes aquestes obres tenen un antecedent llatí.

Encara un altre autor mèdic antic trobà el seu espai entre les versions peninsulars: Hipòcrates, de qui circulen traduccions d'obres com la Capsula eburnea traduïda al castellà ( I 500 ad quem) a partir d'una versió àrab, i florilegis coneguts amb el títol d'Aforismes (dues versions catalanes del segle XIV lligades probablement a centres universitaris, una de les quals conservada en dos testimonis). Sota el nom d'Hipòcrates, el món medieval conegué innumerables opuscles mèdics, tres dels quals ens han arribat en versions castellanes del segle Xv, procedents versemblantment de colleccions llatines; són el Libro abreviado sobre las bestias, el Libro de la verdad i els Prognostica. ${ }^{16}$ Aquestes obres es coneixen en testimoni únic i no sabem res dels seus traductors o compiladors.

També ha arribat en un únic testimoni, vinculat a Alfons el Savi, la traducció castellana del Tetrabiblos de Ptolemeu, feta a partir d'un original àrab. Aquesta obra tracta d'astrologia, una ciència que els «físics» havien de conèixer, car condicionava l'aplicació d'alguns tractaments mèdics com ara les sagnies, però que també interessava els grans senyors, ja que les decisions

is Ara a la Biblioteca Pública d'Évora on foren a parar els fons procedents dels Jesuïtes i de la Universitat.

${ }^{16}$ Aquestes obres no consten a BETA com a traduccions, sinó com a obres originals pseudohipocràtiques. 
polítiques transcendents s'havien de prendre tenint en compte les posicions dels astres. ${ }^{17}$

\section{Filosofia}

Les obres medievals són plenes d'esments d'autoritat, sovint iniciats per la fórmula «Diu lo philosoph», i aquest «philosoph» s'identifica sovint amb Aristòtil. ${ }^{18}$ Així, doncs, la tradició medieval d'obres del «Philosoph» és molt ampla i sota el seu nom circularen nombrosos compendis i florilegis de sentències, el més conegut dels quals és el Secreta secretorum (és a dir, els Poridat de poridades, Secrets dels secrets, etc.). Deixarem aquí de banda la immensa obra del pseudo-Aristòtil per centrar-nos en la tradició de les obres d'autoria més contrastada (seguint l'edició Bekker). En portuguès, no es conserva cap versió medieval i en català només són tres les obres a considerar, totes transmeses per un únic testimoni: el Regiment d'alberg, les Ètiques traduïdes des del llatí per Guillem de Copons (I 4 I 8-I467) dedicades a la reina vídua Violant de Bar i una altra obra que no és ben bé d'Aristòtil, sinó que es tracta d'un comentari a la seva Econòmica ${ }^{19}$ redactat en italià per Leonardo Bruni i traduït per Martí de Viciana (I48 I-I 492) a València amb una dedicatòria a la seva esposa Damiata.

Les versions catalanes del Regiment i de les Ėtiques són de la primera meitat del segle xv i la de Martí de Viciana de finals de segle. Aquesta distància cronològica coincideix amb un canvi en la forma d'entendre la filosofia: medievalitzant en el cas de les Ėtiques dedicades a la reina vídua com a consolació, i obertament humanística en el cas del Comentari a l'econòmica, que proporciona a un públic ciutadà (no allunyat de la cort) l'accés a la discussió filosòfica contemporània.

El panorama és molt més ampli en castellà, llengua en què tenim documentades tres versions de les Étiques (amb un total de setze manuscrits i tres edicions incunables), una de la Filosofia moral traduïda pel príncep Carles de Viana (edició postincunable), una anònima de la Dialéctica (Topica) (manuscrit únic) i la d'Alonso de Cartagena de l'Oeconomica (quatre testimonis manuscrits). Bona part d'aquestes traduccions es vinculen als cercles nobiliaris de la cort castellana i de l'aragonesa i totes parteixen de versions llatines. També tenen un públic nobiliari les traduccions de Pedro Díaz de Toledo dels diàlegs de Plató: el Phaedo (tres còpies manuscrites) i l'Axiochus (un únic testimoni).

Ultra aquests autors reconeguts per l'ortodòxia filosòfica i dels quals podem parlar d'uns clars antecedents grecs, trobem encara una versió dels Libros teosóficos atribuïts a Hermes Trismegist feta a partir del llatí per Diego Guillén

${ }^{17}$ És ben coneguda l'afició del rei Pere el Cerimoniós pels textos astrològics i la seva protecció als savis que conreaven aquesta ciència a la Corona d'Aragó (Chabás).

${ }^{18}$ El Corpus aristotelicum inclou una sèrie d'obres d'Aristòtil amb les d'altres autors que diuen ser Aristòtil i va circular àmpliament durant l'edat mitjana a tot Europa ( $c f$. Bekker ed.).

I9 Text, però, d'autoria discutida. 
de Ávila a Roma en ${ }^{48} 5$ (manuscrit únic) i la de la Vita Secundi Pbilosopho que en castellà procedeix de la versió incorporada per Vincent de Beauvois al seu Speculum historiale, traduïda al castellà al segle Xv (preservada en tres manuscrits). La Vitae es difon en el cercle dels Reis Catòlics, mentre que els Tratados foren traduïts a Roma, a la cort papal.

Finalment, farem esment del Regiment d'alberg de Brison (Baraçan), obra que arribà al català al segle xIv després de passar per versions àrabs i llatines, segons ha demostrat recentment Jaume Riera (Lo Breviari).

\section{Literatura}

La major part dels testimonis són en castellà, amb dues versions fragmentàries de la Iliada de mitjan segle xv i vinculades a Santillana, la primera traduïda per Pedro González de Mendoza y Figueroa (manuscrit únic) i la segona anònima (dues còpies manuscrites conservades). Un altre cas és el dels sis manuscrits i una edició de la Ilias llatina, en versió castellana de ca. I 442 feta per Juan de Mena per al rei Joan II, car la Ilias només es pot considerar una traducció del grec si es fa servir un criteri molt ampli, car creiem que seria millor considerarla com una obra autònoma (González Rolán 7-25).

També vinculades amb l'entorn nobiliari castellà de mitjan segle XV són les dues versions dels Diálogos de Llucià de Samòsata, fetes a partir de la llatina de Giovanni Aurispa, una per al comte d'Haro (tres manuscrits conservats) i l'altra per a Luis de Silva (cinc còpies manuscrites medievals).

De finals del segle xv és la traducció de les Vitae et fabulae d'Isop, obra que va tenir set edicions i que un desconegut va traduir del llatí o de la versió alemanya, qüestió encara per resoldre. ${ }^{20}$ Molt anterior (finals del segle XII o inicis del XIII?) era la versió portuguesa del Livro de Esopo, la procedència de la qual desconeixem.

En català, la llista és minsa i les obres a considerar força discutibles. ${ }^{21}$ Les Lletres d'Alexandre al rei Dídimus procedeixen en últim terme de la Collatio Alexandri magni cum Dindimo Rege Bragmanorum de Philosophia per litteras facta, que, al seu torn, reprèn un fragment del Commonitorium Palladi, obra grega atribuïda a Pal.ladi, bisbe d'Helenòpolis (segles IV-v). Tenim en català dues versions d'aquestes lletres, una traduïda a partir del text llatí de l'Speculum historiale de Vincent de Beauvois (un manuscrit lligat a cercles nobiliaris) i l'altra interpolada a la Historia de preliis (dos manuscrits); com és evident, l'original grec queda molt lluny d'aquestes versions vulgars.

També és discutible parlar d'una traducció del grec si ens referim a la $H$ istoria de preliis de Leo Napolitanus. L'obra fou redactada en llatí, tot i que està

\footnotetext{
${ }^{20}$ La versió catalana d'Isop és posterior a les dates que estem considerant.

${ }^{21}$ Prenem aquestes dades i construïm la nostra argumentació a partir de Cabré i Pujol (document electrònic consultat l'abril de 2010).
} 
fortament relacionada amb antecedents grecs de la història d'Alexandre. La traducció catalana és de finals del segle xIV o inicis del xv i es conserva en dos manuscrits. Temps abans, però, el text fou emprat pels compiladors alfonsins $\mathrm{i}$ amplis extractes foren incorporats a la General estoria (segle XIII), interpretant el text com una font històrica rellevant (Sánchez-Prieto Borja I cii-ciii).

La difusió d'aquest tipus d'obres és típicament cortesana, lligada als cercles nobiliaris on les novetats que venien d'Itàlia eren molt ben rebudes. Recordem l'interès que es té perquè Leonardo Bruni ensenyi a Castella o el present triat per Giovanni d'Aurispa, que posà en les mans dels grans senyors de la cort castellana - on havia arribat per negociar qüestions relatives al Concili de Basilea- la seva traducció llatina dels Diálogos de Llucià de Samòsata, text que gràcies a la competència entre bibliòfils tingué més d'una versió castellana. Les traduccions fragmentàries de la Iliada probablement tenen el mateix origen.

El quadre dibuixat de les versions d'obres gregues ens mostra com pràcticament totes són indirectes. Les castellanes se situen dins d'una literatura d'entreteniment, destinada a l'erudició d'un públic noble i cultivat, però dejú de llatí. Les catalanes i les portugueses són obres d'un caire pràctic: d'aplicació a ciències com la medicina i d'ús pels seus professionals; de reflexió filosòfica o moral o de reflexió espiritual ${ }^{22}$ i, per tant, vinculades al creixement interior, ben acollides en ambients eclesiàstics, ciutadans i nobiliaris. Aquest sentit pràctic de la literatura que té un origen en obres gregues només divergeix en dues obres traduïdes al català: el Polibi i l'Econòmica.

Francesc Alegre dedicà al conseller de Barcelona Antoni de Vilatorta en I 472 la traducció del Polibi feta a través de la versió italiana de Leonardo Bruni. Aquesta traducció respon al mateix esperit de curiositat envers les novetats que Itàlia proporciona com a mitjancera entre el món oriental i l'Europa de tradició medieval i no està gaire lluny dels interessos que posaren en les mans de Santillana o d'Haro les obres de Llucià, d'Homer o de Plató. Fou en un ambient semblant, però valencià, on Martí de Viciana (home, però, també vinculat a la cort reial) posava en català el comentari «moderníssim» de Bruni a l'Econòmica d'Aristòtil.

Fins on arriben els nostres coneixements sobre la història d'aquestes traduccions, els seus traductors i els testimonis que les transmeten, observem que les versions del segle XIV tenen en totes les llengües peninsulars uns mateixos orígens i públic, mentre que a la segona meitat del segle xv, quan a Castella s'acumulen les peces preparades per al consum de l'elit noble de la cort de Joan II, no trobem uns ambients similars generadors d'obres ni a Portugal ni a Catalunya.

GEMMA AVENOZA

UNIVERSITAT DE BARCELONA-IRCVM

${ }^{22}$ Aquí unificaríem la categoria de filosofia amb la de vida espiritual. 
VIDA ESPIRITUAL

\begin{tabular}{|c|c|c|c|c|c|}
\hline \multirow[b]{2}{*}{ Autor i obra } & \multicolumn{5}{|c|}{ BITECA } \\
\hline & data trad. & $\begin{array}{l}\text { llengua } \\
\text { intermèdia }\end{array}$ & traductor & $\begin{array}{l}\text { ambient o } \\
\text { destinatari }\end{array}$ & tradició textual \\
\hline $\begin{array}{l}\text { Isaac de Nínive, Liber de } \\
\text { accessu animae }\end{array}$ & $\begin{array}{l}\mathrm{I} 373 \mathrm{a} \\
\text { quo?- } 1450 \\
\text { ad quem }\end{array}$ & $\begin{array}{l}\text { siríac }>\text { grec } \\
>\text { llatí? }\end{array}$ & Anònim & $\begin{array}{l}\text { monàstic? } \\
\text { monàstic? }\end{array}$ & $\begin{array}{l}2=\text { Esc N.i. } 6 \\
\text { BUB } 148^{4} 8\end{array}$ \\
\hline $\begin{array}{l}\text { Isaac de Nínive, Liber de } \\
\text { accessu animae }\end{array}$ & $\begin{array}{l}\mathrm{I} 373 a \\
\text { quo? }\end{array}$ & $\begin{array}{l}\text { siríac > grec } \\
>\text { llatí? }\end{array}$ & Anònim & monàstic? & $\begin{array}{l}I=\text { SevCol } \\
5-3-4^{2}\end{array}$ \\
\hline Verba seniorum (Pascasi) & $\begin{array}{l}\mathrm{I} 43^{8} \text { ad } \\
\text { quem }\end{array}$ & llatí? & $\begin{array}{l}\text { Anònim; al } \\
\text { llatí Pascasio } \\
\text { de Dumio }\end{array}$ & monàstic & $\mathbf{I}=\mathrm{BUB} 559$ \\
\hline $\begin{array}{l}\text { Verba seniorum, Apotegmes } \\
\text { (Pelagius) }\end{array}$ & $1301-I 330$ & llatí & Anònim & $\begin{array}{l}\text { monàstic } \\
\text { monàstic }\end{array}$ & $\begin{array}{l}2=\mathrm{LB} \text { Add } \\
\text { I } 6433 \text { Montserrat } \\
\text { 8 } 10\end{array}$ \\
\hline $\begin{array}{l}\text { Apophthegmata patrum } \\
\text { (Pelagi) }\end{array}$ & I300-I350? & llatí? & Anònim & $\begin{array}{l}\text { monàstic } \\
\text { monàstic }\end{array}$ & $\begin{array}{l}\mathbf{2}=\mathrm{BdC}_{263} \\
\text { Tarragona Sts } \\
\text { Creus } 49\end{array}$ \\
\hline Verba seniorum (prol. Rufí) & $\begin{array}{l}\text { I } 458 \text { ad } \\
\text { quem }\end{array}$ & llatí & Anònim & cort? & $\mathrm{I}=\mathrm{BN} 10265$ \\
\hline $\begin{array}{l}\text { Vitae Patrum (St. Anastasius, } \\
\text { Vita sancti Antonii) }\end{array}$ & I390-I4 IO? & llatí? & Anònim & $\begin{array}{l}\text { monàstic } \\
\text { monàstic }\end{array}$ & $\begin{array}{l}2=\text { ACA St. } \\
\text { Cugat } 39 \\
\text { Tarragona Stes } \\
\text { Creus } 49\end{array}$ \\
\hline $\begin{array}{l}\text { Exemples Sts pares }<\text { Rufinus } \\
\text { Aquileia }\end{array}$ & I $30 \mathrm{I}-\mathrm{I} 400 ?$ & llatí & Anònim & monàstic & $\begin{array}{l}\mathbf{I}=\text { ACA St. } \\
\text { Cugat } 59\end{array}$ \\
\hline $\begin{array}{l}\text { Vitae Patrum (St. Anastasius, } \\
\text { Vita sancti Antonii) }\end{array}$ & I $300-1350$ & $\begin{array}{l}\text { llatí Evagri } \\
\text { d'Antioquia }\end{array}$ & Anònim & monàstic & $\begin{array}{l}2=\text { Montserrat } \\
8 \text { I० Bcn Diocesà } \\
\text { fr. } 7\end{array}$ \\
\hline $\begin{array}{l}\text { div. > J. Voragine, Vita St. } M \text {. } \\
\text { Egipciaca }\end{array}$ & I $450-1500$ & llatí & anònim & $?$ & $\begin{array}{l}\mathbf{0 + 2}= \\
\text { Barcelona, } \\
\text { RosenbachI } 494 \\
\text { Barcelona, } \\
\text { Amoros I } 5 \text { i 9ca. }\end{array}$ \\
\hline $\begin{array}{l}\text { div. > Voragine, Liber gestorum } \\
\text { Barlaam et Josaphat }\end{array}$ & I $450-1500$ & llatí & anònim & $?$ & $\begin{array}{l}0+\mathbf{I}= \\
\text { Barcelona, } \\
\text { Rosenbachi } 494\end{array}$ \\
\hline $\begin{array}{l}\text { div. > J. Voragine, Vita St. } \\
\text { Pelagiae }\end{array}$ & $1450-1500$ & llatí & anònim & $?$ & $\begin{array}{l}0+\mathbf{I}= \\
\text { Barcelona, } \\
\text { Rosenbach } 494\end{array}$ \\
\hline
\end{tabular}




\begin{tabular}{|c|c|c|c|c|c|}
\hline \multirow[b]{2}{*}{ Autor i obra } & \multicolumn{5}{|c|}{ BETA } \\
\hline & data trad. & $\begin{array}{l}\text { llengua } \\
\text { intermèdia }\end{array}$ & traductor & $\begin{array}{l}\text { ambient o } \\
\text { destinatari }\end{array}$ & tradició textual \\
\hline $\begin{array}{l}\text { Isaac de Nínive, Liber de } \\
\text { accessu animae }\end{array}$ & $\begin{array}{l}\text { I } 497 \text { ad } \\
\text { quem }\end{array}$ & $\begin{array}{l}\text { siríac > grec } \\
>\text { àrab? > } \\
\text { llatí }\end{array}$ & Anònim & laic? & $\begin{array}{l}\text { O+ I = Sevilla } \\
\text { Ungut Polak } \\
\text { I } 497\end{array}$ \\
\hline $\begin{array}{l}\text { Isaac de Nínive, Liber de } \\
\text { accessu animae }\end{array}$ & I 484 & $\begin{array}{l}\text { siríac > grec } \\
>\text { àrab? > } \\
\text { llatí > català? }\end{array}$ & $\begin{array}{l}\text { Bernardo } \\
\text { Boïl }\end{array}$ & $\begin{array}{l}\text { Pedro } \\
\text { Zapata }\end{array}$ & $\begin{array}{l}\mathbf{I}+\mathbf{I}=\text { MPalacio } \\
\text { II/795 Zaragoza } \\
\text { Hurus I } 489\end{array}$ \\
\hline $\begin{array}{l}\text { Isaac de Nínive, Regla sacada } \\
\text { del libro del abad Isaac }\end{array}$ & $\begin{array}{l}\text { I soo ca. ad } \\
\text { quem }\end{array}$ & $?$ & Anònim & $\begin{array}{l}\text { cort / } \\
\text { Isabel I }\end{array}$ & $\mathbf{I}=$ Esc a.II. $\mathbf{I} 3$ \\
\hline $\begin{array}{l}\text { Apophthegmata patrum } \\
\text { (Pelagi) }\end{array}$ & $\begin{array}{l}\text { I } 380 \mathrm{ca} \text {. ad } \\
\text { quem }\end{array}$ & llatí & Anònim & $\begin{array}{l}\text { cort / } \\
\text { comte } \\
\text { d'Haro }\end{array}$ & $\mathbf{I}=$ BNM 9247 \\
\hline Vitae Patrum (Pseudo-Jeroni) & a. $\mathrm{I} 490$ & llatí & $\begin{array}{l}\text { Gonzalo } \\
\text { García de } \\
\text { Santa María }\end{array}$ & cort & $\begin{array}{l}\text { o+ } 3 \text { = Zaragoza } \\
\text { Hurus I } 490 \text { ca. } \\
\text { Sevilla } 3 \text { comp. } \\
\text { I } 493 \text { Salamanca } \\
\text { I } 498\end{array}$ \\
\hline Johannes Climacus, Scala coeli & $\begin{array}{l}\text { I } 500 \mathrm{ca} \text {. ad } \\
\text { quem }\end{array}$ & llatí & Anònim & ? & $\begin{array}{l}3=\text { Santander } \\
\text { M-I72 Esc a.ii. I } 7 \\
\text { (2 frg.) }\end{array}$ \\
\hline $\begin{array}{l}\text { div. > J. Voragine, Vita St. M. } \\
\text { Egipciaca }\end{array}$ & $\begin{array}{l}\mathrm{I} 425 \mathrm{ca} . \text { ad } \\
\text { quem }\end{array}$ & llatí & anònim & $\begin{array}{l}\text { cort / Reis } \\
\text { Catòlics / } \\
\text { ? }\end{array}$ & $\begin{array}{l}3 \text { = Lázaro } \\
\text { Galdiano4I } \\
\text { Esch.i.I4 } \\
\text { Santander } \\
\text { MenyPel Mi69 }\end{array}$ \\
\hline div. > Vita St. M. Egipciaca & $1300-1325$ & francès & anònim & ? & $\mathbf{I}=$ Esc h.i. I 3 \\
\hline $\begin{array}{l}\text { div. > Voragine, Liber gestorum } \\
\text { Barlaam et Josaphat }\end{array}$ & I $400 \mathrm{ca}$. & llatí & $\begin{array}{l}\text { Gonzalo de } \\
\text { Ocaña }\end{array}$ & $\begin{array}{l}\text { cort / } \\
\text { comte } \\
\text { d'Haro }\end{array}$ & $\mathbf{I}=\mathrm{BNM}$ I 2689 \\
\hline $\begin{array}{l}\text { div. > Liber gestorum Barlaam } \\
\text { et Josaphat }\end{array}$ & $\begin{array}{l}\text { I } 290 \mathrm{ca} . \text { ad } \\
\text { quem }\end{array}$ & llatí & anònim & & $\begin{array}{l}4=\text { BUSal } 2017 \\
\text { BUSal I } 877 \\
\text { BNi80I7 } \\
\text { Strasbourg Univ. } \\
\text { CodHispio }\end{array}$ \\
\hline $\begin{array}{l}\text { div. > J. Voragine, Vita St. } \\
\text { Pelagiae }\end{array}$ & $\mathrm{I} 400 \mathrm{ca}$. & llatí & $\begin{array}{l}\text { Gonzalo de } \\
\text { Ocaña }\end{array}$ & $\begin{array}{l}\text { cort / } \\
\text { comte } \\
\text { d'Haro }\end{array}$ & $\mathbf{I}=\mathrm{BNM}_{\mathrm{I}} 2589$ \\
\hline $\begin{array}{l}\text { div. > J. Voragine, Vita St. } \\
\text { Pelagiae }\end{array}$ & I $427 \mathrm{ad} \mathrm{q}$ & llatí & anònim & $\begin{array}{l}\text { cort / Reis } \\
\text { Catòlics }\end{array}$ & $\mathbf{I}=$ Esc h.i. $\mathbf{I} 4$ \\
\hline $\begin{array}{l}\text { Jacobo diaconus, Vita St. } \\
\text { Pelagiae }\end{array}$ & $\begin{array}{l}\mathrm{I} 380 \text { ad } \\
\text { quem }\end{array}$ & no trad. & $\begin{array}{l}\text { cort / comte } \\
\text { d'Haro }\end{array}$ & $\begin{array}{l}\mathbf{I}=\mathrm{BNM} \\
9247\end{array}$ & \\
\hline
\end{tabular}




\begin{tabular}{|c|c|c|c|c|c|}
\hline $\begin{array}{l}\text { Johannes Crysostomus, Contra } \\
\text { anomios }\end{array}$ & $\begin{array}{l}\text { I } 500 \mathrm{ca} \text {. ad } \\
\text { quem }\end{array}$ & llatí & anònim & $\begin{array}{l}\text { cort / } \\
\text { Santillana }\end{array}$ & $\mathbf{I}=\mathrm{BN}_{103 \mathrm{I}}$ \\
\hline $\begin{array}{l}\text { Johannes Crysostomus, Quod } \\
\text { name }\end{array}$ & $\begin{array}{l}\text { I } 456 \text { ad } \\
\text { quem }\end{array}$ & llatí & anònim & $\begin{array}{l}\text { cort / Reis } \\
\text { Catòlics } 2 \\
\text { / }\end{array}$ & $\begin{array}{l}4+\text { I }=\text { Esc.a iv.7 } \\
\text { Esc h.ii. } 22 \\
\text { BUSali } 720 \\
\text { BUSal2 } 198 \\
\text { Murcia Ariño } \\
\text { Roca I } 487\end{array}$ \\
\hline $\begin{array}{l}\text { Johannes Crysostomus, Libro } \\
\text { de penitencia }\end{array}$ & s. $\mathrm{xv}$ & llatí & anònim & $?$ & $\mathbf{I}=\operatorname{Esc}$ a.iv. $5(2)$ \\
\hline $\begin{array}{l}\text { Johannes Crysostomus, } \\
\text { Tratado de penitencia }\end{array}$ & $\begin{array}{l}\text { I } 500 \mathrm{ca} \text { ad } \\
\text { quem }\end{array}$ & llatí & anònim & $?$ & $\mathbf{I}=$ Esc a.iv. $5(2)$ \\
\hline $\begin{array}{l}\text { Johannes Crysostomus, } \\
\text { Homiliario sobre Mateo }\end{array}$ & $\begin{array}{l}\text { I } 500 \mathrm{ca} \cdot \text { ad } \\
\text { quem }\end{array}$ & llatí & $\begin{array}{l}\text { Alonso de } \\
\text { Palenzuela }\end{array}$ & cort & $\begin{array}{l}3=\text { Esc b.ii.I } 8 \\
\text { Laz Gal } 770 \\
\text { Santander MyPel } \\
\text { M559 }\end{array}$ \\
\hline $\begin{array}{l}\text { Basilius Caesarienses, Expositio } \\
\text { Domine }\end{array}$ & $\begin{array}{l}\text { I530 ca. ad } \\
\text { quem }\end{array}$ & llatí & anònim & $\begin{array}{l}\text { cort / } \\
\text { Felip V }\end{array}$ & $\mathbf{I}=\mathrm{BN}_{74}$ \\
\hline $\begin{array}{l}\text { Basilius Caesarienses, Basilio a } \\
\text { Juliano apóstata }\end{array}$ & $\begin{array}{l}\text { I } 499 \text { ad } \\
\text { quem }\end{array}$ & llatí & anònim & $\begin{array}{l}0+\mathbf{I}= \\
\text { Sevilla } \\
\text { 3alemanes } \\
\text { I499 }\end{array}$ & \\
\hline Basilius Caesarienses, Sermón & $\begin{array}{l}\text { I } 500 \mathrm{ca} \cdot \text { ad } \\
\text { quem }\end{array}$ & llatí & anònim & $\begin{array}{l}\mathbf{I}= \\
\text { Santander } \\
\text { M-I72 }\end{array}$ & \\
\hline $\begin{array}{l}\text { Basilius Caesarienses, De libris } \\
\text { gentilium }\end{array}$ & I $444-\mathrm{I} 445$ & llatí Bruni & $\begin{array}{l}\text { Pedro Díaz } \\
\text { de Toledo? }\end{array}$ & $\begin{array}{l}\text { cort / } \\
\text { Santillana }\end{array}$ & $\mathbf{I}=\mathrm{BNF}$ esp. $45^{8}$ \\
\hline Basilius Caesarienses, Homilia & $1402-1500$ & $\begin{array}{l}\text { llatí } \\
\text { Bessarion }\end{array}$ & anònim & $\begin{array}{l}\text { cort / } \\
\text { Santillana }\end{array}$ & $\begin{array}{l}\mathbf{2}=\mathrm{BN} \text { I0445 } \\
\text { RAHSanR ms } 39\end{array}$ \\
\hline
\end{tabular}

VIDA ESPIRITUAL

\begin{tabular}{|c|c|c|c|c|c|}
\hline \multirow[b]{2}{*}{ Autor i obra } & \multicolumn{5}{|c|}{ BITAGAP } \\
\hline & data trad. & $\begin{array}{l}\text { llengua } \\
\text { intermèdia }\end{array}$ & traductor & $\begin{array}{l}\text { ambient o } \\
\text { destinatari }\end{array}$ & tradició textual \\
\hline $\begin{array}{l}\text { Isaac de Nínive, Liber de } \\
\text { accessu animae }\end{array}$ & $\begin{array}{l}\text { I } 450 \mathrm{ca} \text {. ad } \\
\text { quem }\end{array}$ & no consta & Anònim & $\begin{array}{l}\text { Val } \\
\text { Fernando } \\
\text { de Aragón } \\
\text { Alcobaça } \\
\text { Alcobaça } \\
\text { descon. }\end{array}$ & $\begin{array}{l}4=\text { Rio Jan BN } \\
\text { Cof. so } 2 \text { - Is } \\
\text { BNAlc } 46 \text { I } \\
\text { BNAlc } 28 \text { I Ev } \\
\text { BP CXIII/I-40 }\end{array}$ \\
\hline $\begin{array}{l}\text { Apophthegmata patrum } \\
\text { (Pelagi) }\end{array}$ & $\begin{array}{l}\text { I } 425 \text { ad } \\
\text { quem }\end{array}$ & llatí & Anònim & ? & $\mathbf{I}=$ Brasília UdB \\
\hline $\begin{array}{l}\text { Exemples Sts pares < Rufinus } \\
\text { Aquileia }\end{array}$ & I 376 a quo & no consta & Anònim & ? & $\mathbf{I}=$ Brasília UdB \\
\hline
\end{tabular}




\begin{tabular}{|c|c|c|c|c|c|}
\hline Johannes Climacus, Scala coeli & s. Xv & llatí & Anònim & monàstic & $\mathbf{I}=\mathrm{BN} \mathrm{Alc} 2 \mathrm{I} 3$ \\
\hline $\begin{array}{l}\text { Johannes Climacus, Liber ad } \\
\text { pastorem }\end{array}$ & s.d. & no consta & Anònim & monàstic & $\mathrm{I}=\mathrm{BN} \mathrm{Alc} 2 \mathrm{I} 3$ \\
\hline $\begin{array}{l}\text { Johannes Climacus, Carta abat } \\
\text { Raytu }\end{array}$ & s.d. & llatí & Anònim & monàstic & $\mathrm{I}=\mathrm{BN} \mathrm{Alc} 2 \mathrm{I} 3$ \\
\hline $\begin{array}{l}\text { Johannes Climacus, Speculum } \\
\text { monachorum }\end{array}$ & s.d. & llatí & $\begin{array}{l}\text { Fr. } \\
\text { Francisco de } \\
\text { Melgaço }\end{array}$ & monàstic & $\mathbf{I}=\mathrm{BN} \mathrm{Alc} 2 \mathrm{I} 3$ \\
\hline $\begin{array}{l}\text { Vita sanctae Euphrosinae } \\
\text { virginis }\end{array}$ & s. Xv & llatí & anònim & monàstic & $\begin{array}{l}\text { I }=\text { Lisboa BN } \\
\text { Alc } 462\end{array}$ \\
\hline $\begin{array}{l}\text { Sofronio de Jerusalem, Vida Sta. } \\
\text { M. Egipciaca }\end{array}$ & $1275-1325$ & llatí & anònim & monàstic & $\begin{array}{l}2=\text { Lisboa BN } \\
\text { Alc } 46 \text { I Lis BN } \\
\text { Alc } 462\end{array}$ \\
\hline $\begin{array}{l}\text { Daniel de Raytu, Vita Iohanni } \\
\text { Climaci }\end{array}$ & s. $\mathrm{XV}$ & llatí & anònim & monàstic & $\begin{array}{l}\mathbf{I}=\text { Lisboa BN } \\
\text { Alc } 2 \mathrm{I} 3\end{array}$ \\
\hline $\begin{array}{l}\text { div. > Liber gestorum Barlaam } \\
\text { et Josaphat }\end{array}$ & $\begin{array}{l}\text { I } 370 ?- \\
\text { I } 400 ?\end{array}$ & llatí & anònim & monàstic & $\begin{array}{l}2=\text { Lisboa BN } \\
\text { Alc } 462 \text { Lisboa } \\
\text { Ac Cienc Az } 670\end{array}$ \\
\hline $\begin{array}{l}\text { div. > Voragine, Liber gestorum } \\
\text { Barlaam et Josaphat }\end{array}$ & $1475-1500$ & $\begin{array}{l}\text { llati > } \\
\text { castellà G. F. } \\
\text { de Vagad }\end{array}$ & Anònim & & $\begin{array}{l}\text { o }+ \text { I = Lisboa } \\
\text { Kempen-Rabelo } \\
\text { I } 5 \text { I } 3\end{array}$ \\
\hline Jacobus diaconus, Vita Pelagiae & $\begin{array}{l}\text { I } 4 \text { I } 6 ?- \\
\text { I } 424 ?\end{array}$ & llatí & anònim & monàstic & $\begin{array}{l}3=\text { Lisboa BN } \\
\text { Alc } 46 \text { I Lis BN } \\
\text { Alc } 462 \text { Brasilia } \\
\text { UdB cod }\end{array}$ \\
\hline $\begin{array}{l}\text { div. > J. Voragine, Vita St. } \\
\text { Pelagiae }\end{array}$ & I $440-\mathrm{I} 460 ?$ & llatí & Anònim & $\begin{array}{l}\mathbf{I}= \\
\text { Lisboa, } \\
\text { Kempen- } \\
\text { Rabelo, } \\
\text { I I } 3\end{array}$ & \\
\hline
\end{tabular}

\section{HistòRIA}

\begin{tabular}{|c|c|c|c|c|c|}
\hline \multirow[b]{2}{*}{ Autor i obra } & \multicolumn{5}{|c|}{ BITECA } \\
\hline & data trad. & $\begin{array}{l}\text { llengua } \\
\text { intermèdia }\end{array}$ & traductor & $\begin{array}{l}\text { ambient o } \\
\text { destinatari }\end{array}$ & tradició textual \\
\hline $\begin{array}{l}\text { Polybius, De primo bello } \\
\text { punico }\end{array}$ & I 472 & $\begin{array}{l}\text { llatí > italià } \\
\text { Bruni }\end{array}$ & $\begin{array}{l}\text { Francesc } \\
\text { Alegre }\end{array}$ & $\begin{array}{l}\text { laic i } \\
\text { ciutadà / } \\
\text { Antoni de } \\
\text { Vilatorta / } \\
\text { Convent } \\
\text { del Carme } \\
\text { BUB }\end{array}$ & $\begin{array}{l}\mathbf{2}=\text { NY HS } \\
\mathrm{HC}_{3} 87 / 4327 \\
\text { BUB } 85\end{array}$ \\
\hline $\begin{array}{l}\text { Flavius Josephus, Antiquitates } \\
\text { Judaicae }\end{array}$ & I 408 & llatí & Anònim & $\begin{array}{l}\text { cort / } \\
\text { Joan I }\end{array}$ & $\begin{array}{l}O+\mathbf{I}=\text { Barcelona } \\
\text { Spindeler } \mathrm{I}_{4} 82\end{array}$ \\
\hline
\end{tabular}




\begin{tabular}{|c|c|c|c|c|c|}
\hline \multirow[b]{2}{*}{ Autor i obra } & \multicolumn{5}{|c|}{ BETA } \\
\hline & data trad. & $\begin{array}{l}\text { llengua } \\
\text { intermèdia }\end{array}$ & traductor & $\begin{array}{l}\text { ambient o } \\
\text { destinatari }\end{array}$ & tradició textual \\
\hline $\begin{array}{l}\text { Polybius, De primo bello } \\
\text { punico }\end{array}$ & s. $\mathrm{Xv}$ & $\begin{array}{l}\text { llatí } \\
\text { Decembrio }\end{array}$ & Anònim & $?$ & $\mathbf{I}=\mathbf{B N M} 8822$ \\
\hline $\begin{array}{l}\text { Herodianus de Syria, Historiae } \\
\text { Herodiani }\end{array}$ & I $480-$ I 500 & $\begin{array}{l}\text { italià } \\
\text { Poliziano }\end{array}$ & $\begin{array}{l}\text { Diego } \\
\text { Guillén de } \\
\text { Ávila }\end{array}$ & $\begin{array}{l}\text { cort / } \\
\text { (Roma) }\end{array}$ & $\begin{array}{l}\mathbf{I}=\text { New Haven: } \\
\text { Yale Beinecke } 82\end{array}$ \\
\hline $\begin{array}{l}\text { Flavius Josephus, De bello } \\
\text { indaico }\end{array}$ & $\begin{array}{l}\text { I } 492 \text { ad } \\
\text { quem }\end{array}$ & $\begin{array}{l}\text { llatí R. } \\
\text { Aquileia }\end{array}$ & $\begin{array}{l}\text { Alfonso de } \\
\text { Palencia }\end{array}$ & $\begin{array}{l}\text { cort / } \\
\text { Isabel I }\end{array}$ & $\begin{array}{l}\text { O+ I = Sevilla } \\
\text { Ungut Polak } \\
\text { I } 492\end{array}$ \\
\hline Flavio Josephus, Contra Appion & $\begin{array}{l}\text { I } 492 \text { ad } \\
\text { quem }\end{array}$ & $\begin{array}{l}\text { llatí R. } \\
\text { Aquileia }\end{array}$ & $\begin{array}{l}\text { Alfonso de } \\
\text { Palencia }\end{array}$ & cort & $\begin{array}{l}\circ+\mathrm{I}=\text { Sevilla } \\
\text { Ungut Polak } \\
\text { I } 49^{2}\end{array}$ \\
\hline Xenophon, Hiero & s. $\mathrm{xv}$ & $\begin{array}{l}\text { llatí } \\
\text { Decembrio }\end{array}$ & anònim & cort? & $\begin{array}{l}\text { I }=\text { RAH San } \\
\text { Roman ms } 39\end{array}$ \\
\hline Plutarchus, Vitae parallelae & $\begin{array}{l}\text { I491 ad } \\
\text { quem }\end{array}$ & llatí & $\begin{array}{l}\text { Alfonso de } \\
\text { Palencia }\end{array}$ & cort & $\begin{array}{l}2+\text { I = BN } 892 \\
\text { BN } 7565 \text { Sevilla } \\
\text { Ungut Polak } \\
\text { I 49I }\end{array}$ \\
\hline Plutarchus, Vitae parallelae & I $379-\mathrm{I} 384$ & griego vulgar & $\begin{array}{l}\text { J. Fdz de } \\
\text { Heredia }\end{array}$ & $\begin{array}{l}\text { cort } \\
\text { Nàpols / } \\
\text { Heredia }\end{array}$ & $\begin{array}{l}\mathrm{I}=\text { Paris } \mathrm{BN} \text { esp. } \\
70-72\end{array}$ \\
\hline $\begin{array}{l}\text { Plutharchus, De toda condición } \\
\text { de la nobleza }\end{array}$ & $\begin{array}{l}\text { I } 46 \text { I ad } \\
\text { quem }\end{array}$ & $\begin{array}{l}\text { italià } \\
\text { Decembrio }\end{array}$ & $\begin{array}{l}\text { Carlos de } \\
\text { Viana }\end{array}$ & cort & $\begin{array}{l}2=\mathrm{BN}_{178 \mathrm{I} 4} \\
\mathrm{BN} 23090\end{array}$ \\
\hline Plutarchus, De capienda... & a. 1536 & llatí & $\begin{array}{l}\text { Pedro } \\
\text { Fernández } \\
\text { de Villegas }\end{array}$ & $\begin{array}{l}\text { comte } \\
\text { d'Haro }\end{array}$ & $\mathbf{I}=$ Burgos $\mathrm{BC}$ \\
\hline $\begin{array}{l}\text { Johannes Zonaras, Epitome } \\
\text { bistoriarum }\end{array}$ & I $377-$ I 393 & català? / cap & $\begin{array}{l}\text { J. Fdz de } \\
\text { Heredia }\end{array}$ & $\begin{array}{l}\text { cort / Fdz } \\
\text { de } \\
\text { Heredia } \\
\text { (còpia } \\
\text { Santillana) }\end{array}$ & $\mathrm{I}=\mathrm{BN} \mathrm{IOI} 3 \mathrm{I}$ \\
\hline Crónica de Morea & I 377 -I 393 & francès? & $\begin{array}{l}\text { J. Fdz de } \\
\text { Heredia }\end{array}$ & $\begin{array}{l}\text { cort / Fdz } \\
\text { de Heredia } \\
\text { (còpia } \\
\text { Santillana) }\end{array}$ & $\mathrm{I}=\mathrm{BN} 10 \mathrm{I} 3 \mathrm{I}$ \\
\hline $\begin{array}{l}\text { Eusebius de Cesarea, Chronici } \\
\text { canones }\end{array}$ & I $445-1446$ & $\begin{array}{l}\text { llatí S. Jeroni } \\
i \text { ad. Pròsper }\end{array}$ & $\begin{array}{l}\text { Alfonso } \\
\text { Fernández } \\
\text { de Madrigal } \\
\text { el Tostado }\end{array}$ & $\begin{array}{l}\text { cort / } \\
\text { Santillana }\end{array}$ & $\mathrm{I}=\mathrm{BN} \mathrm{I} 08 \mathrm{II}$ \\
\hline
\end{tabular}




\begin{tabular}{llllll}
\hline DRET & \multicolumn{5}{c}{ BETA } \\
\cline { 2 - 6 } Autor i obra & data trad. & $\begin{array}{l}\text { llengua } \\
\text { intermèdia }\end{array}$ & traductor & $\begin{array}{l}\text { ambient o } \\
\text { destinatari }\end{array}$ & tradició textual \\
\hline Justinianus I, Codicus & $\begin{array}{l}\text { I } 426 \text { ad } \\
\text { quem }\end{array}$ & llatí & Anònim & $\begin{array}{l}\text { cort / D. } \\
\text { Joan I }\end{array}$ & I = ms. perdut \\
\hline
\end{tabular}

\section{Medicina Y CIÈnCIA}

\begin{tabular}{|c|c|c|c|c|c|}
\hline \multirow[b]{2}{*}{ Autor i obra } & \multicolumn{5}{|c|}{ BITECA } \\
\hline & data trad. & $\begin{array}{l}\text { llengua } \\
\text { intermèdia }\end{array}$ & traductor & $\begin{array}{l}\text { ambient o } \\
\text { destinatari }\end{array}$ & tradició textual \\
\hline $\begin{array}{l}\text { Claudius Galenus, Comentari } \\
\text { als aforismes }\end{array}$ & $\mathrm{I} 40 \mathrm{I}-\mathrm{I} 450$ & llatí & Anònim & & $\begin{array}{l}\mathbf{I}=\text { Bordeaux BC } \\
568\end{array}$ \\
\hline $\begin{array}{l}\text { Claudius Galenus, Art de } \\
\text { medicina (J. of Saxony, Flor } \\
\text { dels savis)? }\end{array}$ & $\begin{array}{l}\text { I } 459 \text { ad } \\
\text { quem }\end{array}$ & llatí & Anònim & $?$ & $\mathbf{I}=\operatorname{BdC~} 88 \mathrm{I}$ \\
\hline $\begin{array}{l}\text { Claudius Galenus, Conaxença } \\
\text { de les urines segons Galien }\end{array}$ & $1400-1450$ & grec $>$ llatí & Anònim & $?$ & $\begin{array}{l}4=\text { Paris Arsenal } \\
2525 \text { BNP esp } \\
\text { 508 Vat lat } 4797 \\
\text { BUB } 239\end{array}$ \\
\hline $\begin{array}{l}\text { Claudius Galenus, Microtecne } \\
\text { (Joanniti Art del tigni serveix } \\
\text { d'introducció a aquesta obra) }\end{array}$ & I 399 a quo & llatí & Anònim & $?$ & $\begin{array}{l}4=\text { Vat. Lat } 4797 \\
\text { Paris Ars } 2525 \\
\text { BNP esp. } 508 \\
\text { BUB } 239\end{array}$ \\
\hline $\begin{array}{l}\text { Claudius Galenus, } \\
\text { Remembrança de les lletres a } \\
\text { Coris }\end{array}$ & I $350-1390$ & grec > àrab & Joan Jacme & $\begin{array}{l}\text { cort } \\
\text { aragonesa, }\end{array}$ & $\begin{array}{l}\mathbf{I}=\text { Sarag Cap. } \\
25 / 62\end{array}$ \\
\hline Hippocrates, Aphorismi & I35 I-I $390 ?$ & àrab & Anònim & $?$ & $\begin{array}{l}\mathbf{I}=\text { Toledo } \\
\text { Capitular 96-3I }\end{array}$ \\
\hline $\begin{array}{l}\text { Hippocrates, Aforismes } \\
\text { d'Hipocras }\end{array}$ & I 35 I-I $400 ?$ & llatí & Anònim & & $\begin{array}{l}2=\text { BUVal } 216 \\
\text { Bordeaux } 568\end{array}$ \\
\hline $\begin{array}{l}\text { Pseudo-Hippocrates, De saber } \\
\text { quines són les malalties }\end{array}$ & $1350-1450$ & llatí & Anònim & $?$ & $\begin{array}{l}\mathbf{I}=\text { Andorra la } \\
\text { Vella arxiu } 7 \\
\text { claus frg. }\end{array}$ \\
\hline
\end{tabular}




\begin{tabular}{|c|c|c|c|c|c|}
\hline \multirow[b]{2}{*}{ Autor i obra } & \multicolumn{5}{|c|}{ BETA } \\
\hline & data trad. & $\begin{array}{l}\text { llengua } \\
\text { intermèdia }\end{array}$ & traductor & $\begin{array}{l}\text { ambient o } \\
\text { destinatari }\end{array}$ & tradició textual \\
\hline $\begin{array}{l}\text { Claudius Galenus, Libro que } \\
\text { babla altamente de física }\end{array}$ & I $47 \mathrm{I}$ & llatí? & $\begin{array}{l}\text { Anònim / } \\
\text { copista Juan } \\
\text { de Mayórica }\end{array}$ & $?$ & $\begin{array}{l}\mathbf{I}=\text { Mpalacio } \\
\mathrm{II} / 3063\end{array}$ \\
\hline $\begin{array}{l}\text { Claudius Galenus, Tesoro de los } \\
\text { remedios (extr. Galè) }\end{array}$ & $\begin{array}{l}\text { I } 500 \mathrm{ca} \cdot \mathrm{ad} \\
\text { quem }\end{array}$ & llatí? & Anònim & $\begin{array}{l}\text { comprat a } \\
\text { Burgos }\end{array}$ & $\begin{array}{l}\mathbf{I}=\text { SColombina } \\
5-\mathbf{I}-\mathbf{I} 7\end{array}$ \\
\hline Hippocrates, Capsula eburnea & $\begin{array}{l}\text { I } 500 \mathrm{ca} \text { ad } \\
\text { quem }\end{array}$ & àrab & Anònim & $\begin{array}{l}\mathrm{I}=\mathrm{BUS} \text { al } \\
2262\end{array}$ & \\
\hline $\begin{array}{l}\text { Pseudo-Hippocrates, Libro } \\
\text { abreviado sobre las bestias }\end{array}$ & $\begin{array}{l}\text { I } 500 \mathrm{ca} \text {. ad } \\
\text { quem }\end{array}$ & $\begin{array}{l}\text { no consta } \\
\text { trad. }\end{array}$ & Anònim & cort & $\mathbf{I}=\mathrm{BN}_{3} 668$ \\
\hline $\begin{array}{l}\text { Pseudo-Hippocrates, Libro de } \\
\text { verdad }\end{array}$ & s. $\mathrm{xV}$ & $\begin{array}{l}\text { no consta } \\
\text { trad. }\end{array}$ & Anònim & ? & $\begin{array}{l}\mathbf{I}=\text { Zabalb. } \\
\text { Vitrina }\end{array}$ \\
\hline $\begin{array}{l}\text { Pseudo-Hippocrates, } \\
\text { Prognostica }\end{array}$ & $\begin{array}{l}\text { I } 500 \mathrm{ca} \text {. ad } \\
\text { quem }\end{array}$ & àrab & Anònim & $?$ & $\mathrm{I}=$ BUSal 2262 \\
\hline $\begin{array}{l}\text { Claudios Ptolomaeus, } \\
\text { Tetrabiblos }\end{array}$ & $\begin{array}{l}\text { I } 272 \text { ad } \\
\text { quem }\end{array}$ & àrab & Anònim & $\begin{array}{l}\text { cort } \\
\text { alfonsina }\end{array}$ & $\begin{array}{l}3=\mathrm{SevCol} \\
5-2-32 \mathrm{BN} 3306 \\
\mathrm{BN} \text { I } 866\end{array}$ \\
\hline
\end{tabular}

\section{Medicina I CiÈnCiA}

\begin{tabular}{llllll}
\hline & \multicolumn{5}{c}{ BITAGAP } \\
\cline { 2 - 5 } Autor i obra & data trad. & $\begin{array}{l}\text { llengua } \\
\text { intermèdia }\end{array}$ & traductor & $\begin{array}{l}\text { ambient } 0 \\
\text { destinatari }\end{array}$ & tradició textual \\
\hline $\begin{array}{l}\text { Claudius Galenus, De } \\
\text { anatomia }\end{array}$ & $\begin{array}{l}\text { I } 45 \mathrm{I} \text { ?- } \\
\text { I500? }\end{array}$ & llatí & Anònim & ? & $\begin{array}{l}\text { I }=\text { Ev. BP } \\
\text { CXXI/2-I9 }\end{array}$ \\
\hline
\end{tabular}

FILOSOFÍA

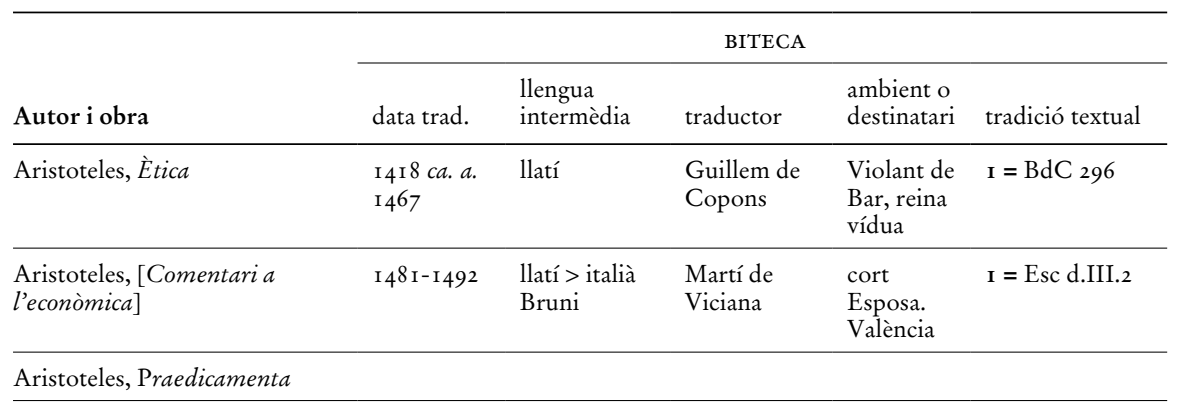


Brison, Oikonomikos (Baraçan, $\quad \mathrm{I} 350-\mathrm{I}_{4} 50$ ? àrab $>$ llatí $\quad$ Anònim $\quad$ ? $\quad \mathrm{I}=\mathrm{BdC}_{42}$ Regiment d'alberg)

Filosofía

\begin{tabular}{|c|c|c|c|c|c|}
\hline \multirow[b]{2}{*}{ Autor i obra } & \multicolumn{5}{|c|}{ BETA } \\
\hline & data trad. & $\begin{array}{l}\text { llengua } \\
\text { intermèdia }\end{array}$ & traductor & $\begin{array}{l}\text { ambient o } \\
\text { destinatari }\end{array}$ & tradició textual \\
\hline Aristoteles, Ètica & I 467 & italià Bruni & $\begin{array}{l}\text { Nuño de } \\
\text { Guzmán y } \\
\text { Torres }\end{array}$ & $\begin{array}{l}\text { cort } \\
\text { castellana }\end{array}$ & $\begin{array}{l}9+2 \text { = Esc k. } \\
\text { ii. I } 3 \text { ACA Ripoll } \\
\text { I6 I BN } 45 \text { I } 4 \text { BN } \\
7076 \text { BN } 67 \text { Io } \\
\text { BN I } 204 \\
\text { Cambridge } \\
\text { Roma Vat Ot lat } \\
\text { 2054 Oxford Bod } \\
\text { span.d. I Sevilla } \\
\text { Ungut-Polak } \\
\text { I493 Zaragoza } \\
\text { Hurus I } 488\end{array}$ \\
\hline $\begin{array}{l}\text { Aristoteles, Ethica ad } \\
\text { Nicomachum }\end{array}$ & $28-07-1458$ & italià Bruni & $\begin{array}{l}\text { Carlos de } \\
\text { Aragón }\end{array}$ & cort & $\begin{array}{l}4+\text { I = Lisboa } \\
\text { BN IL } 2 \text { I } 3 \text { BN } \\
6984 \mathrm{MadPal} \\
\text { II/2990 London } \\
\text { BL Add 2 I I } 20 \\
\text { como Filosofia } \\
\text { moral = } \\
\text { Zaragoza Coci } \\
\text { I } 509\end{array}$ \\
\hline $\begin{array}{l}\text { Aristoteles, Ethica ad } \\
\text { Nicomachum }\end{array}$ & $\begin{array}{l}\text { I } 492 \text { ad } \\
\text { quem }\end{array}$ & llatí & $\begin{array}{l}\text { Anònim o } \\
\text { Nuño de } \\
\text { Guzmán }\end{array}$ & $\begin{array}{l}\text { cort } \\
\text { castellana }\end{array}$ & $\begin{array}{l}2+\text { I }=\text { Compl } \\
\text { Hist. BH MSS } \\
\text { I } 52 \text { BN I0268 } \\
\text { Sevilla } \\
\text { Ungut-Polak } \\
\text { I } 492\end{array}$ \\
\hline Aristoteles, De animalibus & $\begin{array}{l}\text { I } 500 \mathrm{ca} \text {. ad } \\
\text { quem }\end{array}$ & llatí & Anònim & $?$ & $\mathrm{I}=\mathrm{BN}$ 1०198 \\
\hline $\begin{array}{l}\text { Aristoteles, De generatione et } \\
\text { corruptione }\end{array}$ & $\begin{array}{l}\text { I } 500 \mathrm{ca} \cdot \text { ad } \\
\text { quem }\end{array}$ & llatí? & Anònim? & ? & $\begin{array}{l}\mathbf{I}=\mathrm{MadPal} \\
\mathrm{II} / \mathrm{I} 39 \mathrm{I}(\mathrm{I})\end{array}$ \\
\hline $\begin{array}{l}\text { Aristoteles, Filosofia moral } \\
\text { (Politica y económica) }\end{array}$ & $\mathrm{I} 450 \mathrm{ca}$. & llatí & Anònim & cort & $\begin{array}{l}0+\text { I }=\text { Zaragoza } \\
\text { Coci I } 509\end{array}$ \\
\hline Aristoteles, Dialéctica & $\begin{array}{l}\text { I } 500 \mathrm{ca} \cdot \text { ad } \\
\text { quem }\end{array}$ & llatí & Anònim & ? & $\begin{array}{l}\mathbf{I}=\mathrm{MadPal} \\
\mathrm{II} / 960\end{array}$ \\
\hline Aristoteles, Oeconomica & $\begin{array}{l}\text { I } 450 \mathrm{ca} \cdot \mathrm{ad} \\
\text { quem }\end{array}$ & llatí Bruni & $\begin{array}{l}\text { Alonso de } \\
\text { Cartagena? } \\
\text { Anònim al } \\
\text { Rep trad. }\end{array}$ & $\begin{array}{l}\text { cort } \\
\text { castellana }\end{array}$ & $\begin{array}{l}4=\mathrm{RAH} \\
\text { SanRomán } 38 \\
\text { BN I0268 BN } \\
\text { I } 20_{4} \text { Cambridge? }\end{array}$ \\
\hline
\end{tabular}




\begin{tabular}{|c|c|c|c|c|c|}
\hline Aristoteles, Praedicamenta & $\begin{array}{l}\text { I } 500 \mathrm{ca} \cdot \text { ad } \\
\text { quem }\end{array}$ & llatí & Anònim & ? & $\begin{array}{l}\mathbf{I}=\mathrm{MadPal} \\
\mathrm{II} / 960\end{array}$ \\
\hline div. > V. Beauvais, Vita Secundi & s. $\mathrm{xv}$ & llatí & anònim & $\begin{array}{l}\text { ?/ cort } \\
\text { Reis } \\
\text { Catòlics }\end{array}$ & $\begin{array}{l}3=\text { BUSal I } 763 \\
\text { Esc } 3 . \text {.iii. I० Esc } \\
\text { h.iii.I }\end{array}$ \\
\hline $\begin{array}{l}\text { Hermes Trimegistus, Libros } \\
\text { teosóficos }\end{array}$ & I485 & $\begin{array}{l}\text { llatí M. } \\
\text { Ficino }\end{array}$ & $\begin{array}{l}\text { Diego } \\
\text { Guillén de } \\
\text { Ávila }\end{array}$ & cort & $\begin{array}{l}\mathbf{I}=\text { Esc b.iv.29 } \\
(2)\end{array}$ \\
\hline Plato, Axiochus & I $444-\mathrm{I} 445$ & $\begin{array}{l}\text { llatí Cencio } \\
\text { de Rustici }\end{array}$ & $\begin{array}{l}\text { Pedro Díaz } \\
\text { de Toledo }\end{array}$ & $\begin{array}{l}\text { cort / } \\
\text { Santillana }\end{array}$ & $\mathbf{I}=\mathrm{BNF}$ esp. $45^{8}$ \\
\hline Plato, Phaedo & I 458 & llatí Bruni & $\begin{array}{l}\text { Pedro Díaz } \\
\text { de Toledo }\end{array}$ & $\begin{array}{l}\text { cort / } \\
\text { Santillana } \\
\text { / }\end{array}$ & $\begin{array}{l}3=\text { BN Vit I 7-4 } \\
\text { San MyP M96 } \\
\text { BUSal 26I } 4\end{array}$ \\
\hline
\end{tabular}

\section{LITERATURA}

\begin{tabular}{|c|c|c|c|c|c|}
\hline \multirow[b]{2}{*}{ Autor i obra } & \multicolumn{5}{|c|}{ BITECA } \\
\hline & data trad. & $\begin{array}{l}\text { llengua } \\
\text { intermèdia }\end{array}$ & traductor & $\begin{array}{l}\text { ambient o } \\
\text { destinatari }\end{array}$ & tradició textual \\
\hline $\begin{array}{l}\text { Collatio Alexandri Magni cum } \\
\text { Dindimo Rege = Lletres } \\
\text { d'Alexandre }\end{array}$ & s. XV & llatí & Anònim & noblesa & $\mathbf{I}=\mathrm{BdC} \mathrm{I}_{5} 60$ \\
\hline $\begin{array}{l}\text { Historia de preliis Alexandri } \\
\text { Magni }\end{array}$ & I 390-I 4 IO? & $\begin{array}{l}\text { llatí Leo } \\
\text { Napolitanus }\end{array}$ & Anònim & $?$ & $\begin{array}{l}2=\mathrm{BdC} \text { i } 560 \\
\mathrm{BdC} \text { I } 872\end{array}$ \\
\hline $\begin{array}{l}\text { Collatio Alexandri Magni cum } \\
\text { Dindimo Rege = Lletres } \\
\text { d'Alexandre }\end{array}$ & $\mathrm{I} 450 \mathrm{ca}$. & llatí & Anònim & noblesa & $\mathbf{I}=\mathrm{BN}_{78} \mathrm{II}$ \\
\hline
\end{tabular}

\section{LITERATURA}

\begin{tabular}{|c|c|c|c|c|c|}
\hline \multirow[b]{2}{*}{ Autor i obra } & \multicolumn{5}{|c|}{ BETA } \\
\hline & data trad. & $\begin{array}{l}\text { llengua } \\
\text { intermèdia }\end{array}$ & traductor & $\begin{array}{l}\text { ambient o } \\
\text { destinatari }\end{array}$ & tradició textual \\
\hline Homerus, Iliada inc. & $\begin{array}{l}\mathrm{I} 446 \mathrm{ca} . \\
\text { - I } 45^{2}\end{array}$ & $\begin{array}{l}\text { llatí } \\
\text { Decembrio }\end{array}$ & $\begin{array}{l}\text { Pedro } \\
\text { González de } \\
\text { Mendoza y } \\
\text { Figueroa }\end{array}$ & $\begin{array}{l}\text { cort / } \\
\text { Santillana }\end{array}$ & $\begin{array}{l}\mathrm{I}=\text { London } \mathrm{BL} \\
\text { Ad } 2 \text { I } 245\end{array}$ \\
\hline Homerus, Iliada frg. & $\mathrm{I} 45^{2} \mathrm{ca}$ & llatí & anònim & $\begin{array}{l}\text { cort / } \\
\text { Santillana }\end{array}$ & $\begin{array}{l}2=\text { London BL } \\
\text { Ad } 2 \text { I } 245 \text { RAH } \\
\text { Sroman Ms } 39\end{array}$ \\
\hline
\end{tabular}




\begin{tabular}{|c|c|c|c|c|c|}
\hline Ilias llatina (Iliada en romance) & $\mathrm{I} 442 \mathrm{ca}$. & llatí & $\begin{array}{l}\text { Juan de } \\
\text { Mena }\end{array}$ & $\begin{array}{l}\text { cort / } \\
\text { Joan II }\end{array}$ & $\begin{array}{l}6+\text { I = Palma } \\
\text { March 20/5/6 } \\
\text { Sant MenyPel } \\
\text { M96 BN 6052 } \\
\text { BN } 8600 \text { BN } \\
7099 \text { BN } 3666 \\
\text { Valladolid, } \\
\text { Brocar I } 59\end{array}$ \\
\hline $\begin{array}{l}\text { Historia de preliis Alexandri } \\
\text { Magni }\end{array}$ & s. XIII & $\begin{array}{l}\text { llatí Leo } \\
\text { Napolitanus }\end{array}$ & Anònim & $\begin{array}{l}\text { cort Alfons } \\
\text { el Savi }\end{array}$ & General estoria \\
\hline Aesopus, Vita et fabulae & $\begin{array}{l}\mathrm{I} 482 \text { ad } \\
\text { quem }\end{array}$ & $\begin{array}{l}\text { llatí? } \\
\text { Alemany? }\end{array}$ & anònim & $?$ & $\begin{array}{l}0+7=\text { Burgos, } \\
\text { Biel I } 496 \\
\text { Toulouse Paris } \\
\text { I } 488 \text { Zaragoza } \\
\text { I } 49 \text { I Toulouse } \\
\text { Meyer I } 489 \\
\text { Zaragoza } \\
\text { Hurus-Planck } \\
\text { I } 482 \text { Valencia } \\
\text { Joffre I } 520 \\
\text { Zaragoza Hurus } \\
\text { I489 }\end{array}$ \\
\hline Luciano de Samosata, Diálogos & s. Xv? & llatí & $\begin{array}{l}\text { Vasco } \\
\text { Ramírez de } \\
\text { Guzmán? }\end{array}$ & $\begin{array}{l}\text { cort / } \\
\text { comte } \\
\text { d'Haro }\end{array}$ & $\begin{array}{l}3=\mathrm{BN} 9513 \mathrm{BN} \\
9522 \mathrm{BN} 9608\end{array}$ \\
\hline $\begin{array}{l}\text { Luciano de Samosata, Diálogo } \\
\text { sobre la excelencia }\end{array}$ & s. Xv & llatí & $\begin{array}{l}\text { Martín de } \\
\text { Ávila }\end{array}$ & $\begin{array}{l}\text { cort / } \\
\text { Juan de } \\
\text { Silva }\end{array}$ & $\begin{array}{l}5=\text { BN I } 267 \text { BN } \\
3666 \text { USal I } 890 \\
\text { Esc \&.ii.8 Esc } \\
\text { h.ii.22 }\end{array}$ \\
\hline
\end{tabular}

\section{LITERATURA}

\begin{tabular}{llllll}
\hline & \multicolumn{4}{c}{ BITAGAP } \\
\cline { 2 - 5 } Autor i obra & data trad. & $\begin{array}{l}\text { llengua } \\
\text { intermèdia }\end{array}$ & traductor & $\begin{array}{l}\text { ambient o } \\
\text { destinatari }\end{array}$ & tradició textual \\
\hline Aesopus, Vita et fabulae & XII-XIII & llatí? & anònim & $?$ & $\begin{array}{l}\text { I }=\text { Wien NB. } \\
\text { Lat Ser. Vetus } \\
3270\end{array}$ \\
\hline
\end{tabular}




\section{REFERÈNCIES}

Alfons X el SAvi. General estoria. Ed. a cura de Pedro Sánchez Prieto-Borja. Madrid: Fundación José Antonio de Castro, 2009. Io v.

Alvar, Carlos. Traducciones y traductores. Materiales para una bistoria de la traducción en Castilla durante la Edad Media. Alcalá de Henares: Centro de Estudios Cervantinos, 2010.

Alvar, Carlos i José Manuel Lucía. Repertorio de traductores del siglo XV. Madrid: Ollero y Ramos, 2009.

Askins, Arthur L.-F., Harvey L. Sharrer, Aida Fernanda Dias i Martha E. SCHAFFER. BITAGAP (Bibliografia dos testos antigos galegos e portugueses). PHILOBIBLON (I992-). <http://sunsite.berkeley.edu/Philobiblon/ BITAGAP>

AvenozA, Gemma. «Datos sobre el códice M-54 de la Biblioteca Menéndez Pelayo de Santander». Boletín de la Biblioteca Menéndez Pelayo 75 (1999): 393-40I.

-. "Versiones medievales de los Macabeos: San Jerónimo, Josefo y la Megillat Antiochus». V Congreso de la Asociación Hispánica de Literatura Medieval (Santander, 1998). Vol. I. Ed. a cura de M. Freixas et al. Santander: AHLM, Gobierno de Cantabria, 2000. 245-256.

Beltran, Vicenç i Gemma Avenoza. «Per una nova Bibliografia de la Literatura Catalana Antiga». IX Colloqui Internacional de Llengua i Literatura Catalanes. Actes. Vol. I. Barcelona: Publicacions de l'Abadia de Montserrat, I993. 223-238.

Beltran, Vicenç, Gemma Avenoza i Lourdes Soriano. BITECA (Bibliografia de textos antics catalans, valencians $i$ balears). PHILOBIBLON (1992). <http://sunsite.berkeley.edu/Philobiblon/BITECA >

Bekker, Immanuel, ed. Aristòtil, Aristoteles Opera ex recensione I.B. Berlín: De Gruyter, I960-I96I. 5 v.

BorsARI, Elisa. Catálogo de traducciones anónimas al castellano de los siglos XIV a XVI. Madrid: Biblioteca Nacional i Ministerio de Cultura. En premsa.

Bravo García, Antonio Pedro. «Aspectos de la cultura griega en la Península Ibérica durante la Edad Media». Euphrosyne i7 (I989): 36 I-372.

Cabré, Lluís i Josep Pujol. Translat DB. Base de dades de traduccions al català medieval fins a I 500 . Bellaterra: Universitat Autònoma de Barcelona, 2009. <http://www.narpan.net/index.php/translat-db>

Cacho Blecua, Juan Manuel. El gran maestre Juan Fernández de Heredia. Saragossa: Caja de Ahorros de la Inmaculada, i997. Mariano de Pano y Ruata I 2.

ChaвÁs, José. «L'activitat astronòmica a l'època del rei Pere (segle XIV)». La ciència en la història dels Pä̈sos Catalans. Vol. I. Dels àrabs al Renaixement. Barcelona i València: Institut d'Estudis Catalans i Universitat de València, 2004. 483-5I 4 . 
Cifuentes, Lluís. Sciència.cat DB. Barcelona: Universitat de Barcelona, 2009. $<$ http://www.sciencia.cat/>

Coroleu, Alejandro. "A Preliminary Survey of Greek and Latin Historians in Translations in the Iberian Peninsula (c. I360-I 599).» Bulletin of Spanish Studies 8 I (2004): 897-9I 2.

Dias, Aida Fernanda. "A Bibliografia de Textos Antigos Galegos e Portugueses na Internet». Revista Portuguesa de História do Livro I.2 (1998): I73-I 80.

Faulhaber, Charles B. PHILOBIBLON. Berkeley: University of California, Berkeley, 1992. <http://sunsite.berkeley.edu/Philobiblon>

Faulhaber, Charles B. i Ángel Gómez Moreno. «De BOOST a BETA: de Madison a Berkeley». Los códices literarios de la Edad Media. Interpretación, historia, técnicas y catalogación. Direcció de Pedro M. Cátedra. Ed. a cura d'Eva Belén Carro i Javier Durán. Salamanca: CILENGUA, Instituto de Historia del Libro y de la Lectura, 2009. 28 3-292.

Faulhaber, Charles B., Angel Gómez Moreno, Antonio Cortijo Ocaña i Óscar Perea. BETA (Bibliografia de textos españoles antiguos). PHILOBIBLON. (I992-). <http://sunsite.berkeley.edu/Philobiblon/BETA>

González Rolán, T., M. F. del Bario Vega i A. López Fonseca. Juan de Mena. La Ilíada de Homero. Madrid: Ediciones Clásicas, I 996.

Janeras, Sebastià. «La diffusion d'Isaac de Ninive dans la Péninsule Ibérique». Eastern Crossroads. Essays on Medieval Christian Legacy. Ed. a cura de Juan Pedro Monferrer-Sala. Piscataway: Gorgias Press, 2007. 247-274.

LAWRANCE, Jeremy. «Nueva luz sobre la biblioteca del Conde de Haro: inventario de I455». El Crotalón I (1984): I073-I I II.

RIERA I SANs, Jaume. Lo Breviari de baracan lo philòsof en Regiment d'Alberch. En premsa.

-. «Presència de Josefus a les lletres catalanes». Studia in honorem prof. M. de Riquer. Vol. 2. Barcelona: Quaderns Crema, 1987. 179-220.

Ruiz, Elisa. Los libros de Isabel la Católica. Arqueología de un patrimonio escrito. Salamanca: Instituto del Libro y de la Lectura, 2004.

Sabaté i Marín, Glòria i Lourdes Soriano Robles. «Reinas catalanas: mujeres, lectoras y protectoras de la cultura (siglos XIV-Xv)». Mujeres y cultura escrita. Del mito al siglo XxI. Gijón: Trea, 2005. 85-96.

Sánchez Prieto-Borja, Pedro, ed. Alfons X el Savi, General estoria. Madrid: Fundación José Antonio de Castro, 2009. io v. 